UDC 338.012

JEL Classification M31

\author{
Serheev S. ${ }^{a}$, Riabtseva O. ${ }^{a}$, Yavorska M. ${ }^{b}$
}

\title{
ASSESSMENT OF THE PROSPECTS OF NEW COMPANIES IN THE TELECOMMUNICATIONS SERVICES MARKET
}

\author{
${ }^{a}$ Ukrainian State University of Chemical Technology, Dnipro, Ukraine \\ ${ }^{b}$ Social Academy of Sciences in Lodz, Poland
}

\begin{abstract}
The article is about the assessment and analysis of the results of marketing research of the market of telecommunication services in Ukraine. The study of the dynamics of the telecommunications services market allows to draw conclusions about the changes that are associated with the effective use of new information technologies, both by corporate structures, small and medium enterprises for business, and for individual users. In the conditions of a dynamically developing market of telecommunication services, the ability to competently use new telecommunication technologies and marketing tools when promoting new services in order to achieve competitive advantages is of particular importance. The telecommunications services market is a complex system of information flows that can filter and control the transmission and reception of large amounts of information necessary both for business and for individual interested users, as well as promptly transfer information to almost any region and to any enterprise. On the one hand, the growth of the number of operators in the telecommunications market has led to an expansion of the range of services provided, an increase in quality and a decrease in prices for these services. However, on the other hand, in the regions, competition between operators, ultimately, does not contribute to the development of the telecommunications business. Therefore, the marketing mechanism for the formation of competitive relations in the telecommunications market makes theoretical and practical interest. The article also provides information on the importance of telecommunication companies for respondents, assessment of customer satisfaction, wishes and suggestions of consumers in the field of telecommunications. Recommendations on the feasibility of creating a telecommunications company in modern conditions were made.
\end{abstract}

Keywords: marketing research, telecommunications market, questioning, consumer preferences, competitor analysis.

DOI: $10.32434 / 2415-3974-2019-9-1-142-150$

\section{Formulation of the problem}

The study of the dynamics of the telecommunications services market allows to draw conclusions about the changes that are associated with the effective use of new information technologies, both by corporate structures, small and medium enterprises for business, and for individual users. In the conditions of a dynamically developing market of telecommunication services, the ability to competently use new telecommunication technologies and marketing tools when promoting new services in order to achieve competitive advantages is of particular importance.

The relevance of the appeal to the methods of marketing of telecommunication services is caused by the lack of a unified approach to the definition of the essence of such activities of communication operators. In this regard, there is a need to conduct a study, with the help of which it would be possible to evaluate and recommend the most advanced and modern marketing methods in promoting telecommunications services and managing marketing activities of market operators in order to gain competitive advantages.

Currently, marketing research is widely used to obtain relevant, complete and comprehensive information needed to make competent management decisions in the face of uncertainty and risk. Everyone knows that telecommunications technology is a hightech industry that requires great knowledge, skills, 
experience and material investments. To develop recommendations on the feasibility of creating a telecommunications company in modern conditions in terms of reducing risk and overcoming conditions of uncertainty, as well as obtaining information about the market, competitors, and demand for these services, a marketing study of the telecommunications market was conducted. The method of questioning was chosen, since no one knows the consumers preferences better than themselves.

\section{Analysis of research and publications}

Most modern literature attends the significance, the rationale for the need and accuracy of marketing research. The above questions are devoted a lot of textbooks, both foreign and foreign scientists. A weighty contribution to the formation of the theoretical base of marketing research was made by: G.A. Churchill, E.P. Golubkov, I.K. Belyaevsky, M. Meskon, A.V. Kataev, I.V. Lilik, O.V. Kudirko.

In the works of these economists, various sections of the marketing of enterprises and firms were discussed, and various marketing planning algorithms were considered.

At the same time, the practical marketing mechanism for the formation and development of competitive relations in the Ukrainian reality has been worked out practically only in certain particular areas.

The purpose of the article is to study the market of telecommunication services of Ukraine to make a decision about the feasibility of establishing new company in the industry, as well as a general analysis of the telecommunications market.

\section{Presentation of the main material}

To minimize the financial risk arising from the creation of a telecommunications company in modern conditions, it is necessary to hold the analysis of the telecommunications technology market.

The first stage of the marketing research was the analysis of the macromarketing environment, which includes the analysis of political, economic, scientific, technical, socio-cultural, natural and demographic factors. The results of it are shown in Table 1.

The next stage of the research was the analysis of the micromarketing environment, which includes the evaluation of consumers, competitors, suppliers and intermediaries. In marketing researches, as a rule, the focus is on consumers and competitors. Analysis of consumers consists in segmentation of consumers according to various criteria: geographical segmentation consists in dividing the market into various regions, regions, cities; using demographic segmentation, we divide the market into groups according to gender, age, and marital status of the respondents; consumers by income, occupation, level of education.
Consumer analysis was conducted by peer review. The expert group was asked to assess the significance of the factors on a scale of -3 to +3 for each company. The results of the consumer analysis are presented in Table 2. According to the table it is clear that the companies Kyivstar and Vodafone are the main competitors and leading players in the market.

The next stage of the study was the development of search questions, hypothesizing on the main range of issues, as well as identifying sources of information. It was not possible to get answers to some search questions using the analysis of secondary information, therefore survey questionnaires were developed. During the survey, 100 respondents were interviewed. Initially, it was necessary to find out with which company specifically people associate the phrase "telecommunication company". This question was open since its purpose was to determine the popularity of companies. As a result of the survey, $28 \%$ answered "Kyivstar", 22\% of respondents wrote "Vodafone", $19 \%$ answered "Fregat", and 22 people wrote other companies (no more than 2 identical answers for any other company) (Fig. 1 ). This means that, despite the fact that there are several large companies in the Ukrainian telecommunications market that meet the needs of a large proportion of consumers, there are small and medium-sized companies in the market that have found their niche and their customers and successfully function within their segment.

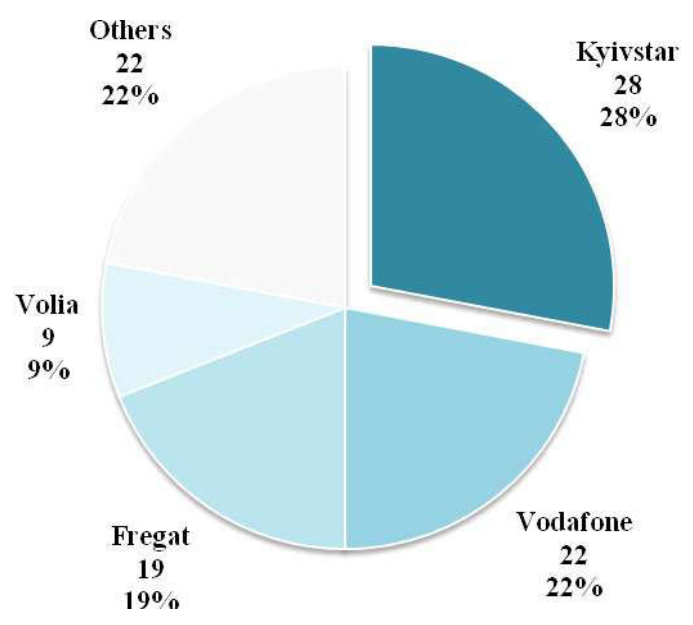

Fig. 1. Respondent's answer to the question: «Which telecommunication company comes to your mind first?»

Then a question followed whether all respondents in the current Internet provider satisfied everything $-48 \%$ of respondents answered "yes", $19 \%$ were dissatisfied, and the remaining $33 \%$ were undecided (Fig. 2). This means that at least $67 \%$ of respondents are either dissatisfied with their provider, 
Analysis of factors of the macromarketing environment

\begin{tabular}{l|c|c|l}
\hline \multicolumn{1}{c|}{ Factor } & Problem $(-)$ & Opportunity $(+)$ & Option to solve a problem or realize opportunities \\
\hline \multicolumn{1}{c|}{ 1 } & 2 & 3 & \multicolumn{1}{c}{} \\
\hline $\begin{array}{l}\text { Imperfect legislative base of } \\
\text { Ukraine }\end{array}$ & - & Political factors \\
\hline $\begin{array}{l}\text { Passive government policy in } \\
\text { the field of antitrust regulation } \\
\text { of the market }\end{array}$ & - & $\begin{array}{l}\text { Cooperation with qualifiedlawyers who will } \\
\text { monitor changes in the memory, and if necessary, } \\
\text { defend our interests in court }\end{array}$ \\
$\begin{array}{l}\text { Mandatory product } \\
\text { certification }\end{array}$ & - & $\begin{array}{l}\text { Drawing public attention to illegal monopoly } \\
\text { actions by specific companies }\end{array}$ \\
$\begin{array}{l}\text { Consumerism } \\
\begin{array}{l}\text { Relative Freedom of } \\
\text { Entrepreneurship }\end{array}\end{array}$ & + & $\begin{array}{l}\text { Conducting transparent communications } \\
\text { customers, respectful attitude to customers }\end{array}$ \\
\hline
\end{tabular}

Economic factors

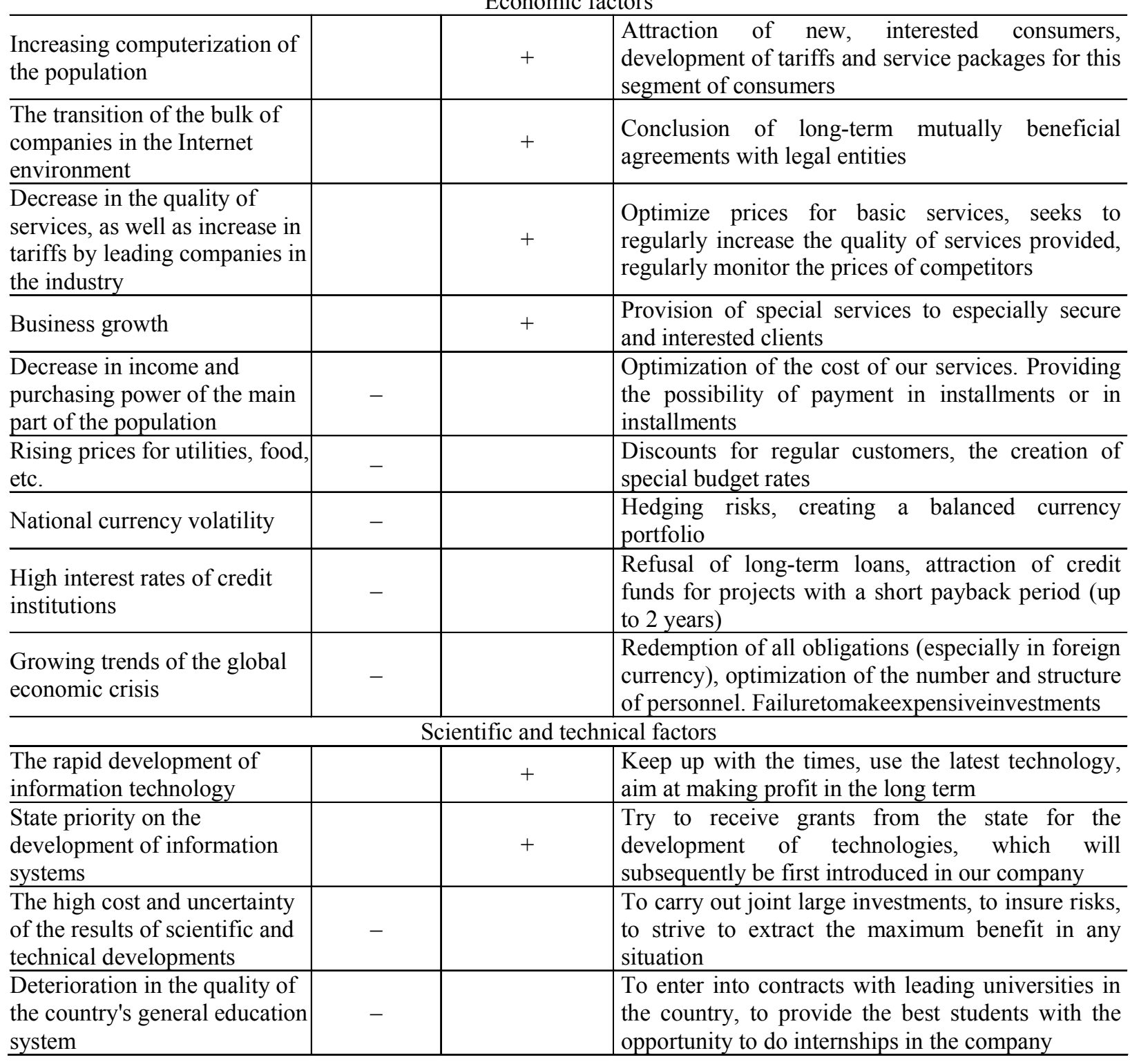


Prodolzheniye tablitsy 1

\begin{tabular}{l|l|l|l}
\hline \multicolumn{1}{c|}{1} & 2 & 3 & \multicolumn{1}{c}{ Socio-cultural factors } \\
\hline $\begin{array}{l}\text { Decline in living standards of } \\
\text { the population }\end{array}$ & - & & Optimization of the cost of services \\
\hline $\begin{array}{l}\text { The needs of the population in } \\
\text { communication, entertainment, } \\
\text { self-expression }\end{array}$ & + & $\begin{array}{l}\text { Providing a variety of tariffs and service options for } \\
\text { each type and category of consumers }\end{array}$ \\
\hline $\begin{array}{l}\text { Geodesic factors (landscape, } \\
\text { terrain, etc.) }\end{array}$ & Natural factors \\
$\begin{array}{l}\text { Availability / shortage of raw } \\
\text { materials }\end{array}$ & + & $\begin{array}{l}\text { Any construction and installation work should } \\
\text { begin with the advice of an expert, conduct } \\
\text { drainage of the area }\end{array}$ \\
\hline $\begin{array}{l}\text { Population reduction } \\
\begin{array}{l}\text { The increasing level of } \\
\text { urbanization of the Ukrainian } \\
\text { population }\end{array}\end{array}$ & $\begin{array}{l}\text { Conclusion of long-term contracts, cooperation } \\
\text { with qualified employees }\end{array}$ \\
\hline
\end{tabular}

Competitor analysis based on expert assessments (from -3 to +3 )

\begin{tabular}{l|c|c|c|c}
\hline \multicolumn{1}{c|}{ Factor } & Kyivstar & Vodafone & Fregat & Ukrtelecom \\
\hline Company fame & +3 & +2 & +1 & 0 \\
\hline Quality of service provided & +1 & +2 & +1 & -1 \\
\hline Advertisingcampaign & +1 & +1 & 0 & -1 \\
\hline Value for money and quality of services provided & 0 & 0 & +1 & -2 \\
\hline Customer Loyalty Program & +1 & +1 & +2 & +1 \\
\hline The work of technical support & +2 & +3 & +2 & +2 \\
\hline Adaptation to changes in the environment & +2 & +1 & +2 & 0 \\
\hline Market share & +3 & +2 & +2 & +1 \\
\hline Reliability & +2 & +2 & +3 & +2 \\
\hline Openness of the company & +1 & +2 & 0 & +2 \\
\hline Innovativeness & +1 & +2 & +2 & +1 \\
\hline Total & +17 & +18 & +15 & +5 \\
\hline
\end{tabular}

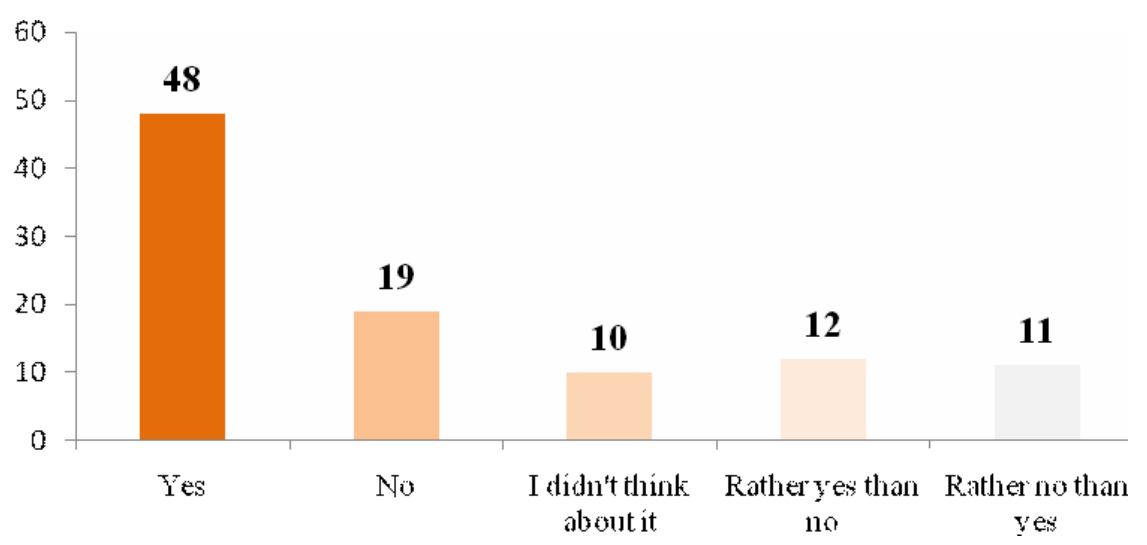

Fig. 2. Respondent's answer to the question: «Does your Internet provider suit you? » 


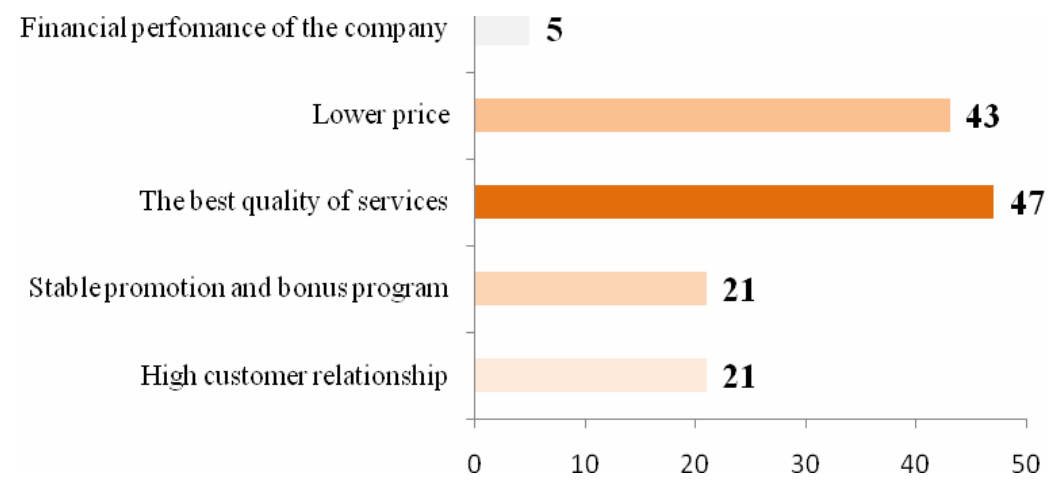

Fig. 3. Respondent's answer to the question: «What made you chance the operator?»

or have not yet decided, which means that this is unmet demand, that is, potential customers.

To the question what would have prompted you to change the operator (who suggested several answer options): $47 \%$ called the best quality of services, $43 \%$ - lower price, $21 \%$ - high level of customer relations, $21 \%$ - stable promotion and bonus program (Fig. 3).

The conservativeness of the respondents was estimated by the following question: "Would you like a new internet service provider (ISP) to appear?". $47 \%$ of respondents answered that they would like to, but only if it would be different from others, $32 \%$ do not deny such an opportunity, $12 \%$ will be glad of any new company, $9 \%$ are not interested in new companies (Fig. 4).

Only $9 \%$ of respondents are not interested in the emergence of new companies. It means that $48 \%$ of respondents who had previously responded that they were completely satisfied with their provider responded either because of the lack of a real alternative from the market, or rushing to choose the answer option to the previous one question.

Then it was analyzed what the speed of the Internet respondents use: $60 \%-100 \mathrm{Mbps}, 25 \%-$ $50 \mathrm{Mbps}, 9 \%-10-25 \mathrm{Mbps}, 6 \%$ - up to $10 \mathrm{Mbps}$ (Fig. 5).

When asked about what kind of gadgets respondents had (one could choose several answers),

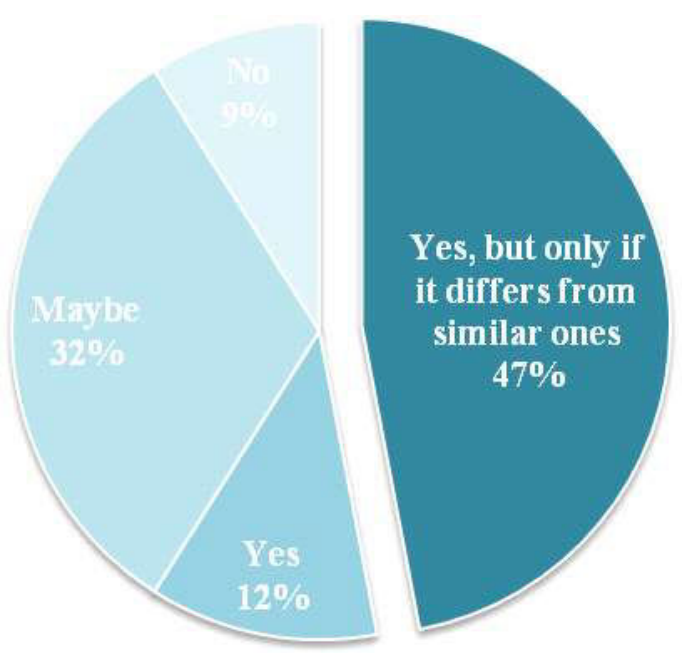

Fig. 4. Respondent's answer to the question: «Would you like that a new ISP to appear?»

the answer was received: $84 \%$ of respondents have a mobile phone, $53 \%$ have a laptop or netbook, $28 \%$ have a tablet computer, $18 \%$ have an e-book, $16 \%$ have smart watches (Fig. 6).

The amount of the monthly subscription fee to a mobile provider of $50 \%$ of respondents is over UAH $100,31 \%$ up to UAH $100,15 \%$ 50-70 UAH, and only $4 \%$ of respondents up to $50 \mathrm{UAH}$ (Fig. 7). Based on the analysis of the above information,

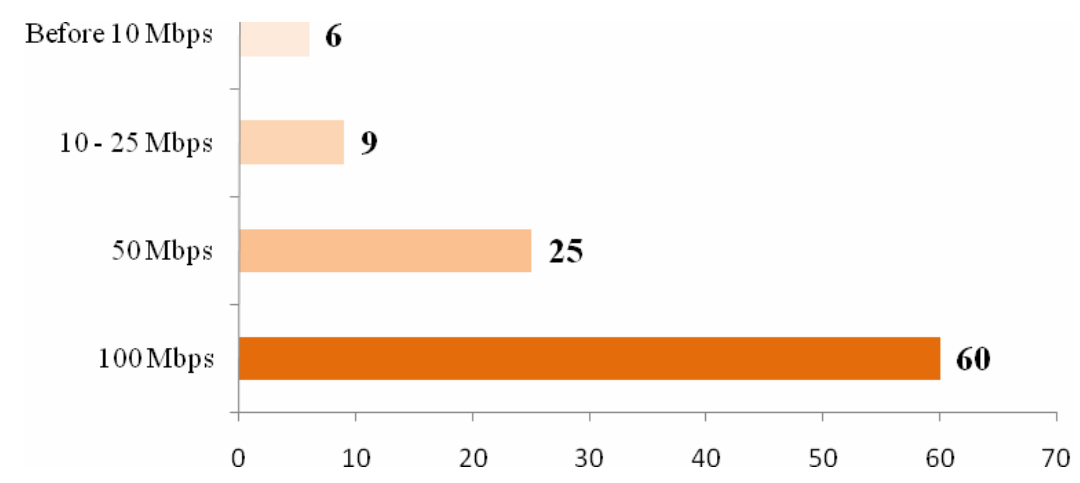

Fig. 5. Respondent's answer to the question: «What is your internet speed? » 


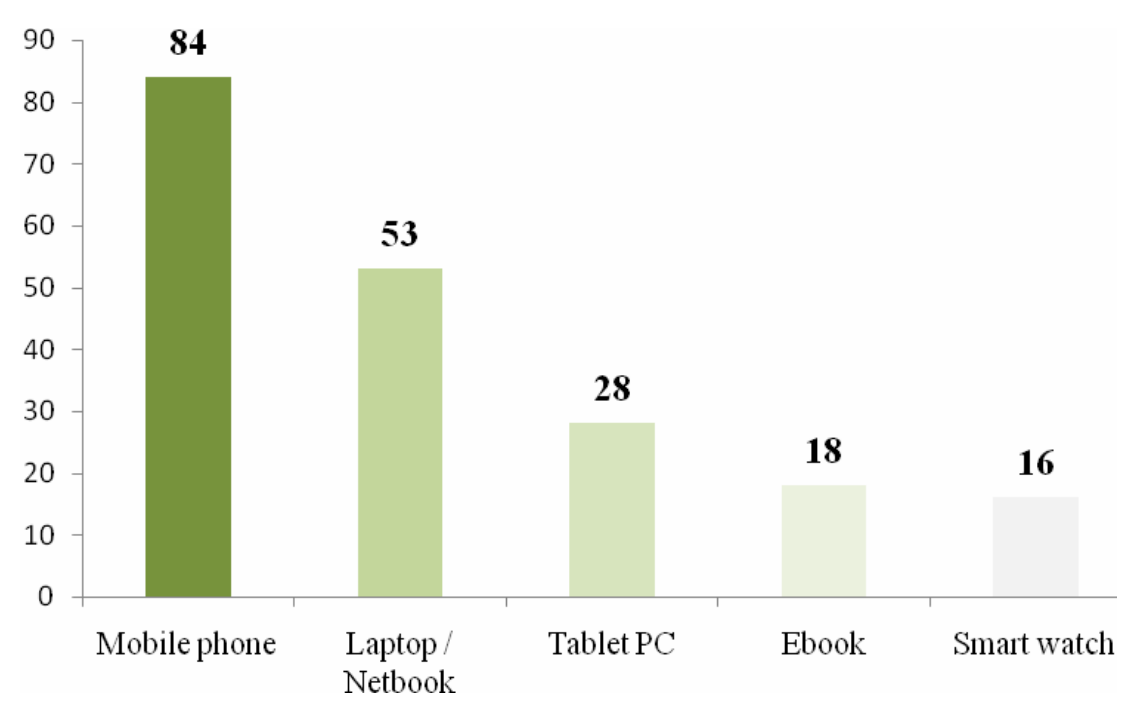

Fig. 6. Respondent's answer to the question: «What is your internet speed?»

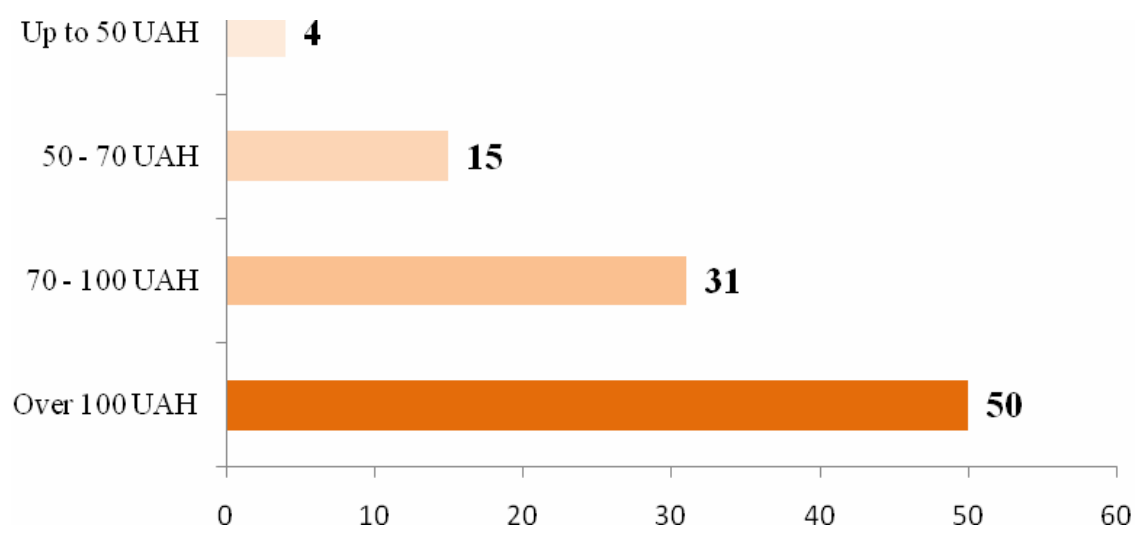

Fig. 7. Respondent's answer to the question: «What is the monthly fee for your mobile operator?»

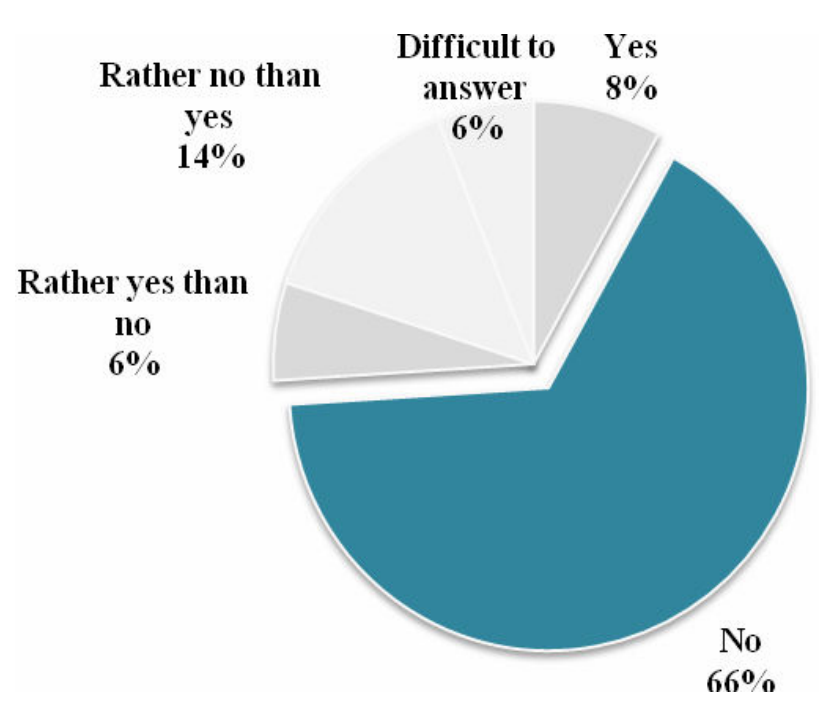

Fig. 8. Respondent's answer to the question: «Are you ready to sacrifice quality for the sake of low prices?» it becomes clear that the payment of telecommunications services, the purchase and updating of gadgets has a priority over other expenses. This means that the needs of the population in highspeed mobile and cable Internet, in a modern mobile phone, productive computer, smart devices are constant and increasing annually. This allows new companies to enter the market with a unique offer and occupy a certain niche.

When asked whether consumers are ready to sacrifice quality for the sake of low prices, the following answers were received: $66 \%$ of respondents are not ready to sacrifice quality, $26 \%$ are in thought and only $8 \%$ agree to this (Fig. 8).

Also in the questionnaire was the question of what, according to respondents, is the most important for a telecommunications company: $74 \%$ believe that this is the optimal price-quality ratio of the service provided, $11 \%$ - round-the-clock technical support work, $8 \%$ - transparency of relations with the client, $6 \%$ - respectful attitude to the client and only $1 \%$ 


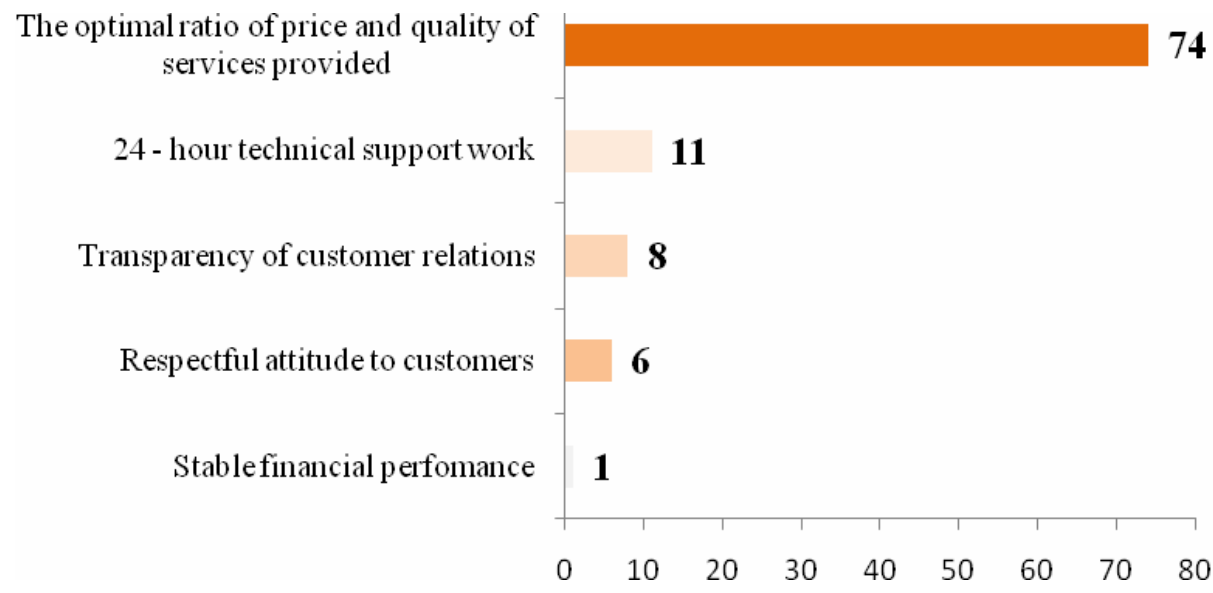

Fig. 9. Respondent's answer to the question: «What is most important for a telecommunications company?»

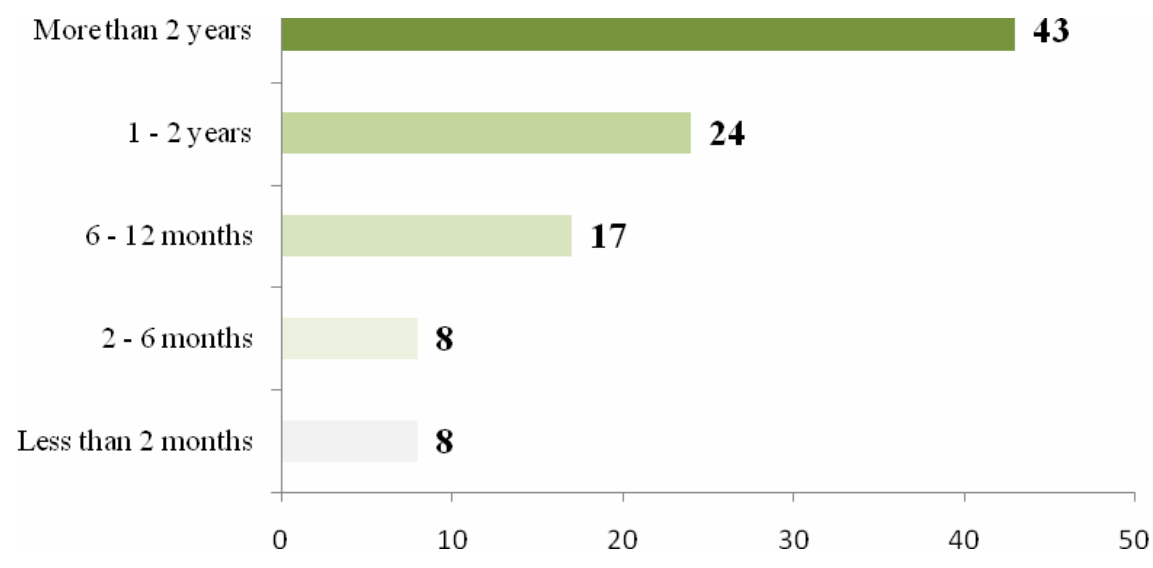

Fig. 10. Respondent's answer to the question: «How long have you been using the latest Internet service provider?»

indicated that this is a stable financial performance of the company (Fig. 9).

To the question about the duration of cooperation with the last Internet provider $43 \%$ responded - over 2 years, $24 \%-1-2$ years, $17 \%-$ 6-12 months, $16 \%$ - less than 6 months (Fig. 10).

There were $61 \%$ male and $39 \%$ female of the 100 respondents surveyed. Representatives of the following age categories participated in the study: $6 \%$ - under the age of 15 years, $46 \%-16-25$ years, $22 \%-25-40$ years, $15 \%-40-55$ years, and $11 \%$ $-55+$ years.

\section{Conclusions}

The conducted marketing research showed that the most discussed and recognizable among consumers are the companies Kyivstar and Vodafone, that once again proves the role of these giants in the market of telecommunication services in Ukraine. Of the respondents surveyed, $60 \%$ have an Internet speed of $100 \mathrm{Mbps}$, and 50\% pay more than 100 hryvnias per month to their operator, but still they are not satisfied with the quality of services provided and $46 \%$ are ready to change the company to the one that can provide the required quality level. Such data suggests that in this market there is unmet effective demand, which is looking for a real alternative to the "old-timers" of the industry. This conclusion is confirmed by the fact that $66 \%$ of respondents are not willing to sacrifice the quality of services for the sake of low prices, $26 \%$ are undecided and only $8 \%$ of respondents agree to this. The next interesting point is that despite the situation described above, $43 \%$ of respondents use the services of their last Internet service provider for more than 2 years. That means that they don't see any real alternatives or are subject to little change by external environment and competitors, which can be a problem for the new company. It is also worth noting that $46 \%$ of respondents are young people between the ages of 16 and 25, but despite the fact that the level of income at this age is often low, young people consider telecommunications services a priority for the distribution of their income. This means that in the future, with an increase in the income of this category of the population, their costs for meeting telecommunication needs will increase.

Based on the analysis performed, we can safely say that creating new telecommunications company 
in modern conditions is appropriate, even if it fail to become an industry leader. A new market participant may concentrate its efforts on a separate market segment, become significant for a certain category of people or perform work, provide services to larger and more influential companies. As a study of the Ukrainian telecommunications services market showed, in order to achieve success in this industry, you need to be result-oriented, do your job efficiently and effectively, which guarantees a steady income from business activities.

\section{REFERENCES}

1. Berezin I.S. Marketing research. Instructions for use. Moscow: Yurayt, 2012.

2. Kameneva N.G. Marketing research: studies. - Moscow: University textbook, 2006.

3. Golubkov E.P. Marketing research: theory, methodology and practice. - Moscow: Publishing house «Finpress». - 1998.

Received15.04.2019 Reviewer: Prof. Kolesnikov V.P.

\section{ОЦІНКА ПЕРСПЕКТИВ НОВИХ КОМПАНІЙ НА РИНКУ ТЕЛЕКОМУНІКАЦІЙНИХ ПОСЛУГ}

\section{Сергєєв С.С., Рябцева О.С., Яворська М.}

Дослідження динаміки ринку телекомунікаційних послуг дозволяє зробити висновки про зміни, які пов 'язані з ефективним використанням нових інформаційних технологій, як корпоративними структурами, малими та середніми підприємствами для бізнесу, так і індивідуальними користувачами. В умовах динамічного розвитку телекомунікаційних послуг вміння ефективно використовувати нові телекомунікаційні технології, маркетингові інструменти при просуванні нових послуг з метою досягнення конкурентних переваг набуває особливого значення. Ринок телекомунікаційних послуг - це складна система інформаційних потоків, яка може фільтрувати і контролювати передачу і прийом великих масивів інформації, необхідних як для ведення бізнесу, так $і$ для індивідуально зацікавлених користувачів, а також оперативно передавати інформацію практично в будь-який регіон $і$ на будь-яке підприємство. 3 одного боку, зростання числа операторів телекомунікаційного ринку привело до розширення спектра послуг, що надаються, підвищення якості та зниження цін на ці послуги. Однак, з іншого боку, в регіонах конкуренція між операторами, в кінцевому рахунку, не сприяє розвитку телекомунікаційного бізнесу. Тому маркетинговий механізм формування конкурентних відносин на ринку телекомунікацій становить теоретичний і практичний інтерес. У статті також надана інформація про значущість телекомунікаційних компаній для респондентів, оцінювання задоволеності споживчого попиту, побажання та пропозиції споживачів в області телекомунікацій. Запропоновано рекомендації щодо доцільності створення телекомунікаційної компанії в сучасних умовах.

Ключові слова: маркетингові дослідження, ринок телекомунікацій, анкетування, переваги споживачів, аналіз конкурентів.

\section{ОЦЕНКА ПЕРСПЕКТИВ НОВЫХ КОМПАНИЙ НА РЫНКЕ ТЕЛЕКОММУНИКАЦИОННЫХ УСЛУГ}

\section{Сергеев С.С., Рябцева О.Е., Яворска М.}

Исследование динамики рынка телекоммуникационных услуг позволяет сделать выводы об изменениях, которые связаны с эффективным использованием новых информационных технологий, как корпоративными структурами, малыми и средними предприятиями для бизнеса, так и для индивидуальных пользователей. В условиях динамично развивающегося рынка телекоммуникационных услуг умение грамотно использовать новые телекоммуникационные технологии, маркетинговые инструменты при продвижении новых услуг с иелью достижения конкурентных преимуществ приобретает особое значение. Рынок телекоммуникационных услуг - это сложная система информационных потоков, которая может фильтровать и контролировать передачу и прием больших массивов информации, необходимых как для ведения бизнеса, так и для индивидуальных заинтересованных пользователей, а также оперативно передавать информацию практически в любой регион и на любое предприятие. С одной стороны, рост числа операторов телекоммуникационного рынка привело к расширению спектра предоставляемых услуг, повышению качества и снижению иен на эти услуги. Однако, с другой стороны, в регионах конкуренция между операторами, в конечном счёте, не способствует развитию телекоммуникационного бизнеса. Поэтому маркетинговый механизм формирования конкурентных отношений на рынке телекоммуникаций представляет теоретический и практический интерес. В статье также представлена информация о значимости телекоммуникационных компаний для респондентов, оценка удовлетворенности потребительского спроса, пожелания и предложения потребителей в области телекоммуникаций. Предложены рекомендации о целесообразности создания телекоммуникационной компании в современных условиях.

Ключевые слова: маркетинговые исследования, рынок телекоммуникаций, анкетирование, предпочтения потребителей, анализ конкурентов. 


\section{ASSESSMENT OF THE PROSPECTS OF NEW COMPANIES IN THE TELECOMMUNICATIONS SERVICES MARKET}

Serheev S. ${ }^{a}$, Riabtseva O. ${ }^{a, *}$, Yavorska M. ${ }^{b}$

a Ukrainian State University of Chemical Technology, Dnipro, Ukraine

${ }^{\mathrm{b}}$ Social Academy of Sciences in Lodz, Poland

* e-mail: ryabtseva.olga@gmail.com

The article is about the assessment and analysis of the results of marketing research of the market of telecommunication services in Ukraine. The study of the dynamics of the telecommunications services market allows to draw conclusions about the changes that are associated with the effective use of new information technologies, both by corporate structures, small and medium enterprises for business, and for individual users. In the conditions of a dynamically developing market of telecommunication services, the ability to competently use new telecommunication technologies and marketing tools when promoting new services in order to achieve competitive advantages is of particular importance. The telecommunications services market is a complex system of information flows that can filter and control the transmission and reception of large amounts of information necessary both for business and for individual interested users, as well as promptly transfer information to almost any region and to any enterprise. On the one hand, the growth of the number of operators in the telecommunications market has led to an expansion of the range of services provided, an increase in quality and a decrease in prices for these services. However, on the other hand, in the regions, competition between operators, ultimately, does not contribute to the development of the telecommunications business. Therefore, the marketing mechanism for the formation of competitive relations in the telecommunications market makes theoretical and practical interest. The article also provides information on the importance of telecommunication companies for respondents, assessment of customer satisfaction, wishes and suggestions of consumers in the field of telecommunications. Recommendations on the feasibility of creating a telecommunications company in modern conditions were made.

Keywords: marketing research, telecommunications market, questioning, consumer preferences, competitor analysis.

\section{REFERENCES}

1. Berezin I.S. (2012) Marketingovyie issledovaniya. Instruktsiya po primeneniyu [Marketing research. Instructions for use], Moscow, Yurayt [in Russian].

2. Kameneva N. G. (2006) Marketingovyie issledovaniya [Marketing research: studies] Moscow, University textbook [in Russian].

3. Golubkov E.P. (1998) Marketingovyie issledovaniya: teoriya, metodologiya i praktika [Marketing research: theory, methodology and practice], Moscow, Publishing house «Finpress» [in Russian]. 